\title{
Probabilistic estimation of glacier volume and glacier bed topography: the Andean glacier Huayna West
}

V. Moya Quiroga ${ }^{1}$, A. Mano ${ }^{2}$, Y. Asaoka ${ }^{1}$, K. Udo ${ }^{2}$, S. Kure ${ }^{2}$, and J. Mendoza ${ }^{3}$

${ }^{1}$ Graduate School of Engineering, Tohoku University, Sendai, Japan

${ }^{2}$ International Research Institute of Disaster Science, Tohoku University, Sendai, Japan

${ }^{3}$ Instituto de Hidraulica e Hidrologia, Universidad Mayor de San Andres, La Paz, Bolivia

Received: 8 July 2013 - Accepted: 29 July 2013 - Published: 7 August 2013

Correspondence to: V. Moya Quiroga (moyav@ potential1.civil.tohoku.ac.jp,

vladyman@ hotmail.co.uk)

Published by Copernicus Publications on behalf of the European Geosciences Union.

Title Page

Abstract

Conclusions

Tables

14

$<$

Back

Full Screen / Esc

Printer-friendly Version

Interactive Discussion 


\section{Abstract}

Glacier retreat will increase sea level and decrease fresh water availability. Glacier retreat will also induce morphologic and hydrologic changes due to the formation of glacial lakes. Hence, it is important not only to estimate glacier volume, but also to 5 understand the spatial distribution of ice thickness. There are several approaches for estimating glacier volume and glacier thickness. However, it is not possible to select an optimal approach that works for all locations. It is important to analyse the relation between the different glacier volume estimations and to provide confidence intervals of a given solution. The present study presents a probabilistic approach for estimatin volume and its confidence interval. Glacier volume of the Andean glacier Huayna West was estimated according to different scaling relations. Besides, glacier volume and glacier thickness were estimated assuming plastic behaviour. The present study also analysed the influence of considering a variable glacier density due to ice firn densification. It was found that the different estimations are described by a lognormal probability distribution. Considering a confidence level of $90 \%$, the estimated glacier volume is $0.0275 \mathrm{~km}^{3} \pm 0.0052 \mathrm{~km}^{3}$. Considering a confidence level of $90 \%$, the estimated glacier thickness is $24.98 \mathrm{~m}$ with a confidence of $\pm 4.67 \mathrm{~m}$. The mean basal shear stress considering plastic behaviour is $82.5 \mathrm{kPa}$. The reconstruction of glacier bed topography showed the future formation of a glacier lake with a maximum depth of $32 \mathrm{~m}$.

\section{Introduction}

Glaciers may be considered as the most important water reservoirs since they store $68.7 \%$ of the world's total fresh water (Gleick, 1996). Unfortunately, they are retreating. Glacier area loss was observed in the Alps (Paul et al., 2007), in the Andes (Ramirez et al., 2001), in Africa (Kaser et al., 2004), in the Himalayas (Naito et al., 2012), in Oceania (Hoelze et al., 2007), in the Antarctic (Rignot, 1998) and in the Arctic (Lenaerts
Probabilistic estimation of glacier volume and glacier bed topography

V. Moya Quiroga et al.

Title Page

Abstract Introduction

Conclusions

Tables

References

Figures

14

$\rightarrow I$

4

Back

$\triangleright$

Close

Full Screen / Esc

Printer-friendly Version

Interactive Discussion 
et al., 2013). Different studies showed that glacier retreat will influence sea level rise and water shortage. Dyurgeyov and Meier (2005) estimated that mountain glaciers may induce a sea level rise of approximately $0.65 \mathrm{~m}$. This level rise may result in a spatial shift of coastal lines (Crooks, 2004) and flooding of some delta areas (Dissanayake 5 et al., 2009). Glacier retreat will also affect water resources. Glacier retreat will induce changes in the streamflow that will affect the water availability downstream (Vuille et al., 2008). Thus, it is important to estimate glacier volume in order to predict future water availability and sea level rise (Kaser et al., 2010; Raper and Braithwaite, 2006).

Field measurement campaigns are a direct method for estimating glacier volume. 10 Glacier thickness and glacier volume can be estimated using ground-penetrating radar (GPR) (Singh et al., 2010; Degenhardt, 2009; Monnier et al., 2011; Navarro et al., 2005; Lee et al., 2010) and radio echo sounding (RES) (Andreassen et al., 2012; Jacobell et al., 2010; Dowdeswell and Evans, 2004; Goodman, 1975). However, GPR and RES are impractical methods for remote and extensive glaciers. Hence, new and 15 simpler alternatives for estimating glacier thickness and glacier volume have been developed. Farinotti et al. (2009) combined mass balance and ice-flow dynamics. Mathematical ice-flow models were developed as an analytical alternative that allows estimating glacier thickness (Colgan et al., 2012; Goldberg and Sergienko, 2011). Such methods require glacier velocity, which is also difficult to obtain; in fact, some studies use ice-flow models for the estimation of glacier velocity (Wang et al., 2012; Debolskaya and Isaenov, 2010; Ren et al., 2012; Calvo et al., 2010). Other studies combine such models with ground-measured data (Farinotti et al., 2013; Zekollari et al., 2013; Colgan et al., 2012). Other studies use analytical models for the estimation of mass balance (Michel et al., 2013; Morlighem et al., 2011). Kääb (2000) combined an iceflow model with photogrammetric data for the reconstruction of glacier mass balance in the Swiss Alps. A different approach is the combination of field-measured data with regression techniques in order to develop empirical relations between glacier thickness and certain local characteristics (Peduzzi et al., 2010; Clarke et al., 2009). However, the latest method lacks a physical background and can only be applied locally.
Probabilistic estimation of glacier volume and glacier bed topography

V. Moya Quiroga et al.

Title Page

Abstract Introduction

Conclusions

Tables

References

Figures

14

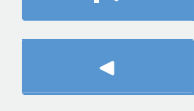

$>$ I

$\triangleright$

Back

Close

Printer-friendly Version

Interactive Discussion 
Other studies tried to develop universal methods. Bahr et al. (1997) developed a physically based volume-area power-law scaling relation. This relation is based on ice dynamics constraints due to ice rheology and typical climatic-topographic conditions of glacierized areas. Nevertheless, such a relation depends on two empirical pa5 rameters. Several studies suggested different values for such parameters (Chen and Ohmura, 1990; Meier and Bahr, 1996; Baraer et al., 2012). Thus, this method is prone to an important degree of uncertainty. Nevertheless, this is the most practical method for estimating glacier volume. Besides, some studies suggest that the initial uncertainties of scaling methods are small when analysing future glacier evolution (Radic et al., 10 2008). One limitation of this method is that it only predicts the total glacier volume, neglecting the distributed thickness.

Spatially distributed glacier thickness is valuable information since it would allow us to predict the glacier bed topography (GBT) (Binder et al., 2009). Such a GBT is important for modelling the glacier evolution (Huss et al., 2010), for estimating possible 15 changes in the runoff regime (Huss et al., 2008), and for predicting the formation of future lakes (Frey et al., 2010). According to Uchupi et al. (2001), the morphology imparted by glaciation has important consequences on drainage characteristics and in some cases may regulate the discharge. Some studies suggest that sub-glacial processes are related to volcanic activity (Scharrer et al., 2008). Other studies suggest that sub-glacial drainage may have storage and delayed discharge, influencing the flow of the ice sheet (Bælum and Benn, 2011; Thoma et al., 2010). Some glacial lakes may be covered by glaciers, but after glacier retreat such lakes are exposed (Sawagaki et al., 2012). Glacial lakes may overflow and fail, causing outburst floods (Tadono et al., 2012). Actually, several flood events due to glacial lakes have already been reported (Komori et al., 2012).

A new and more practical approach for estimating glacier ice thickness and glacier volume is the glacier bed topography (GlabTop) approach proposed by Paul and Linsbauer (2012). Assuming a plastic behaviour, glaciers flow easily enough to redistribute mass and prevent stresses from rising above a given limit (Cuffey and Paterson, 2010;
Probabilistic

estimation of glacier

volume and glacier

bed topography

V. Moya Quiroga et al.

Title Page

Abstract

Introduction

Conclusions

Tables

References

Figures

14

$\rightarrow 1$

4

Back

$\checkmark$

Close

Full Screen / Esc

Printer-friendly Version

Interactive Discussion 
Nye, 1967); thus, the basal shear stress is equivalent to the plastic yield stress. Such a plastic assumption is supported by field measurements showing that glacier deformation is best reproduced considering a plastic deformation (Kavanaugh and Clarke, 2006). GlabTop assumes the glacier thickness as a function of surface slope and basal 5 shear stress. Such assumptions were successfully applied to glaciers in different parts of the world (Li et al., 2012; Paul and Linsbauer, 2012; Linsbauer et al., 2012). Recently, Clarke et al. (2013) proposed to estimate a basal shear stress for different glacier flow units defined by their ice catchment, and then to estimate glacier thickness. However, the latest method requires the ice flux, which is a difficult value to obtain.

10 In the present study we assume that there is not a unique absolute solution for estimating glacier volume; all the proposed methods have some degree of probability and neglecting some estimations may lead to biased conclusions. Glacier volume and glacier thickness of the Andean glacier Huayna West were estimated by the different proposed scaling relations. Besides, distributed glacier thickness and glacier volume were estimated by the GlabTop method, considering different possible values of basal shear stress and analysing the differences between the consideration of a constant glacier density and depth-variable glacier density. Then, the estimations were statistically compared and analysed. It was found that the different volume estimation methods are best explained by a lognormal probability distribution function. Then, the probable glacier volume and glacier thickness were expressed considering appropriate confidence intervals. With the spatially distributed glacier thickness, it was possible to reconstruct the glacier bed topography (GBT). The GBT shows the formation of a future lake. The estimated area-depth ratio of such a lake fits reasonably with observed ratios of glacial lakes from other locations.

\section{Study area}

The study area is the Huayna West glacier in the Bolivian Andes. It is located on the west side of Huayna Potosí, a massif mountain with a maximum elevation of $6088 \mathrm{~m}$

Probabilistic

estimation of glacier

volume and glacier

bed topography

V. Moya Quiroga et al.

Title Page

Abstract

Introduction

Conclusions

Tables

References

Figures

14

$\rightarrow 1$

4

Back

$\checkmark$

Close

Full Screen / Esc

Printer-friendly Version

Interactive Discussion 
above sea level (ma.s.I.). Huayna Potosí is located $30 \mathrm{~km}$ north of La Paz, Bolivia. It separates the dry Altiplano in the west from the wet Amazonian Basin in the east. Due to these climatological differences, the equilibrium line altitude (ELA) of the west side (5700 m a.s.l.) is shifted almost $1 \mathrm{~km}$ above the eastern ELA (Condom et al., 2007). 5 Huayna glacier is located in the Capricorn tropic, where the climate is characterized by two seasons with a period of precipitation and a dry period (Mote and Kaser, 2007). It has a wet season during the austral summer (November-March) and a dry season during the austral winter (April-October). This glacier is highly related to the water supply of La Paz-El Alto conurbation (Bolivia), and is currently being studied within 10 the Glacier Retreat impact Assessment and National policy DEvelopment (GRANDE) project.

\section{Methodology}

Glaciers were delineated using remote sensing data from the Advanced Visible and Near Infrared Radiometer type 2 sensor (AVNIR-2) of the Advanced Land Observa15 tion Satellite (ALOS). The observation date of the image was 6 May 2010. The ALOS AVNIR-2 images were analysed and processed with the multispectral image data analysis system software (Landgrebe, 2005; Dundar and Landgrebe, 2004). The images were classified using an unsupervised classification that allowed distinguishing into four different coverage types: impoundments, rocky ground, bare soil and glaciers (Fig. 1).

It is important to note that the ALOS AVNIR-2 image is more recent than the respective image used for the Randolph Glacier Inventory 3.0, which was observed on 31 May 2003. Besides, it was not possible to use the GLIMS database, since such a database does not include this glacier (Raup et al., 2007).

The flow lines were obtained by processing the global digital elevation model 25 (GDEM) provided by the advanced spaceborne thermal emission and reflection radiometer (ASTER). It is important to remember that surface slope is the dominant factor on bed stress (Nye, 1954). Thus, the surface slope $\alpha$ may be assumed equal
Probabilistic estimation of glacier volume and glacier bed topography

V. Moya Quiroga et al.

Title Page

Abstract Introduction

Conclusions

Tables

References

Figures

14

$\rightarrow 1$

4

Back

$\checkmark$

Close

Full Screen / Esc

Printer-friendly Version

Interactive Discussion 
to the bed slope (Clarke et al., 2013). Although some studies used SRTM (Shuttle Radar Topography Mission) data for studying glaciers and estimating glacier volume (Cooper et al., 2010; Surazakov and Aizen, 2006), in the present study we used the GDEM ASTER since it is a more recent product with better resolution and provides 5 an accurate delineation of the study area. The DEM was processed with the TauDEM algorithm implemented in the GIS software MAPWINDOWS (Tarboton, 1997). Overlaying the delineated basin over a remote sensing image of the study area shows that the delineated basin accurately matches the topography (Fig. 2).

Then, glacier thickness was estimated at the flow-path lines assuming perfect plas10 ticity and the GlabTop approach (Linsbauer et al., 2012) described by Eq. (1).

$h=\frac{\tau}{\rho g \sin \theta}$,

where $h$ is the glacier thickness $(\mathrm{m}), \tau$ the basal shear stress $(\mathrm{kPa}), g$ the gravity acceleration $\left(9.79 \mathrm{~ms}^{-2}\right)$, and $\theta$ the slope $\left({ }^{\circ}\right)$. The most popular estimation of basal shear stress is to consider it as a function of the elevation range of the glacier (Eqs. 2 15 and 3); however, it is important to note that since tropical glaciers have high mass balance gradients, it is reasonable to expect a higher basal shear stress described by Eq. (4), instead of Eq. (3) (Haeberli and Hoelze, 1995).

$\tau=0.005+1.598 \Delta H-0.435 \Delta H^{2}$ if $\Delta H \leq 1.6$

$\tau=150$ if $\Delta H>1.6$

20 $\tau=3 \Delta H$ for $\Delta H \leq 0.5$,

where $\Delta H(\mathrm{~km})$ is the elevation range of the glacier.

Thus, the basal shear stress may be any value between the limits imposed by the above-mentioned equations. In the present study we estimated glacier depth considering both limits and the average. The first basal shear stress from Eq. (2) was denoted as $\tau 1(64.20 \mathrm{kPa})$, the second basal shear stress from Eq. (4) as $\tau 2(136.50 \mathrm{kPa})$, and the average basal shear stress was denoted as $\tau 3(100.35 \mathrm{kPa})$.
Probabilistic estimation of glacier volume and glacier bed topography

V. Moya Quiroga et al.

Title Page

Abstract Introduction

Conclusions

Tables

References

Figures

14

$\rightarrow I$

4

Back

Close

Full Screen / Esc

Printer-friendly Version

Interactive Discussion 
Glacier density is usually assumed as a constant value of $900\left(\mathrm{~kg} \mathrm{~m}^{-3}\right)$ independent of the depth (Linsbauer et al., 2012; Paul and Linsbauer, 2012; Li et al., 2012). However, it is important to consider that the progressive transformation of snow into ice describes a density-depth relation (Cuffey and Patterson, 2010). Recent studies state 5 that the assumption of a constant density may induce important errors in geodetic studies (Huss, 2013). Hence, in the present study both cases were considered: a constant density and a depth-variable density. The density-depth relation was assumed to respond to a parabolic equation (Shumsky, 1960). The density-depth relation was obtained using density measurements from different Andean glaciers (Ginot, 2001). The density-depth relation was described by Eq. (5).

$\rho=-0.2586 d^{2}+18.411 d+569.9$,

where $d$ is the glacier depth $(\mathrm{m})$ and $\rho$ is the glacier density $\left(\mathrm{kg} \mathrm{m}^{-3}\right)$ at such depth. However, such a relation provides the density at a specific depth. In order to get an average density of a glacier column of a given depth, an additional relation was obtained considering that any computed density at a given depth remains constant for intervals of $1 \mathrm{~m}$. Average density for different depths was then computed by

$\overline{\rho_{k}}=\frac{\sum_{i=1}^{k} \rho_{i}}{k}$

where $\overline{\rho_{k}}$ is the average density for a glacier column of depth $k, \rho_{i}$ the glacier density at depth $i$ and $i$ is an integer number.

Then, the glacier thickness points were geo-referenced and the distributed glacier thickness was estimated by applying a kriging interpolation, which is an interpolation technique widely used in glaciological and hydrological studies (Bamber et al., 2013, 2009; Binaghi et al., 2013; Sørensen et al., 2011). Before the interpolation, the outline of the glacier was assumed to have a thickness of $1 \mathrm{~m}$. This assumption was done in order to limit the boundaries to be interpolated and to avoid possible negative values.
Probabilistic

estimation of glacier

volume and glacier

bed topography

V. Moya Quiroga et al.

Title Page

Abstract

Introduction

Conclusions

Tables

References

Figures

14

$>$ I

4

Back

$\triangleright$

Close

Full Screen / Esc

Printer-friendly Version

Interactive Discussion 
The distributed glacier thickness maps allowed obtaining the glacier volume and average thickness. The glacier volume was obtained by multiplying each thickness by its area $\left(900 \mathrm{~m}^{2}\right)$. The average thickness was estimated by averaging the glacier thickness values. Considering the two possible densities and the three possible values of 5 the basal shear stress, we have six possible glacier volumes and six possible average thickness values.

In order to evaluate the results, glacier volume was estimated by other available methods. The most popular method is the area-volume scaling relationship (Bahr et al., 1997). This method relates glacier volume and glacier area by a power-law scaling 10 relation (Eq. 7).

$$
V=c A^{\gamma}
$$

where $A$ is the area of the glacier $\left(\mathrm{km}^{2}\right), V$ the volume of the glacier $\left(\mathrm{km}^{3}\right), \gamma$ the scaling exponent and $c$ a proportional constant. The value of gamma depends on the geometry of the glaciers. Different studied glaciers from different locations developed volume-area scaling relations with different values between 0.02 and 0.0597 for $c$ and between 1.12 and 1.5 for $\gamma$. (Macheret et al., 1984; Yafeng et al., 1981; Meier and Bahr, 1996; Radic and Hock, 2010; Grinsted, 2013). Adhikari and Marshall (2012) suggest different equations according to the glacier mean slope, glacier area and shape factor defined as the width-length ratio. Besides, recent studies showed that $\gamma$ also depends on the transient state of the glaciers; glaciers under warmer scenarios may have $\gamma$ values higher than 2.0 (Radic et al., 2007). Analysing area volume data of the last $60 \mathrm{yr}$ of the extinct glacier Chacaltaya (Francou et al., 2000; Ramirez et al., 2001), we found a $\gamma$ value of 2.0207 and a $c$ value of 0.1091 .

Recent studies stressed the importance of calculating glacier volume by considering 25 thickness-area scaling relationships (Eq. 8). Thus, in the present study we also considered four thickness-area relationships (Huss and Farinotti, 2012; Ohara et al., 2013; Bodin et al., 2010; Nicholson et al., 2009). Three of such relationships were previously
Probabilistic estimation of glacier volume and glacier bed topography

V. Moya Quiroga et al.

Title Page
Abstract

Conclusions

Tables

14

4

Back
Introduction

References

Figures

$\rightarrow 1$

$\checkmark$

Close
Full Screen / Esc

Printer-friendly Version

Interactive Discussion 
developed and applied to South American Andean glaciers.

$\bar{h}=c A^{\gamma}$,

where $\bar{h}$ is the mean glacier thickness $(\mathrm{m})$. Then, multiplying the mean thickness by the area gives the volume.

5 Considering the 6 initial possible volumes, the 24 volumes from the volume-area relationships and the 4 volumes from the thickness-area relationships, we have a total of 34 possible glacier volumes (Table 1).

Since the selection of an arbitrary single solution may lead to bias and wrong estimations, a statistical analysis was performed in order to get the most probable solution.

10 Thus, a statistical analysis was performed in order to find the probability distribution function (PDF) that describes the best of the different volume estimations. Seven probability distribution functions were considered:

- Beta distribution is described by Eq. (9).

$$
\mathrm{PDF}=\frac{(x-a)^{\alpha_{1}-1}(b-x)^{\alpha_{2}-1}}{B\left[\alpha_{1}, \alpha_{2}\right](b-a)^{\alpha_{1}+\alpha_{2}-1}},
$$

where $\alpha_{1}$ and $\alpha_{2}$ are shape parameters of the distribution, $a$ and $b$ boundary parameters, $B$ the beta function and $x$ the variable.

- Exponential distribution is described by Eq. (10).

$$
\operatorname{PDF}=\lambda e^{-\lambda x},
$$

where $\gamma$ is the scale parameter of the distribution.

- Gamma distribution is described by Eq. (11).

$\mathrm{PDF}=\frac{\beta^{-\alpha} x^{\alpha-1} e^{\frac{-x}{\beta}}}{\Gamma(\alpha)}$,

Probabilistic

estimation of glacier

volume and glacier

bed topography

V. Moya Quiroga et al.

Title Page

Abstract

Introduction

Conclusions

References

Tables

Figures

14

- I

4

Back

Close

Full Screen / Esc

Printer-friendly Version

Interactive Discussion 
where $\alpha$ and $\beta$ are the shape parameters of the distribution, and $\Gamma$ is the gamma function.

- Logistic distribution described by Eq. (12).

$$
\mathrm{PDF}=\frac{e^{-\frac{x-\mu}{\sigma}}}{\sigma\left(1-e^{-\frac{x-\mu}{\sigma}}\right)^{2}},
$$

where $\sigma$ is the scale parameter and $\mu$ the location parameter of the distribution.

- Lognormal distribution is described by Eq. (13).

$$
\text { PDF }=\frac{1}{x \sqrt{2 \pi \sigma^{2}}} e^{\frac{-(\ln (x)-\mu)^{2}}{2 \sigma^{2}}}
$$

- Normal distribution is described by Eq. (14).

$$
\text { PDF }=\frac{1}{\sqrt{2 \pi \sigma^{2}}} e^{\frac{-(x-\mu)^{2}}{2 \sigma^{2}}}
$$

- Weibull distribution is described by Eq. (15).

$$
\mathrm{PDF}=\frac{\alpha}{\beta}\left(\frac{x}{\beta}\right)^{\alpha-1} e^{-\left(\frac{x}{\beta}\right)^{\alpha}}
$$

\section{Full Screen / Esc}

Printer-friendly Version

The distributions were evaluated considering the tests of chi-square, KolmogorovSmirnov and Anderson-Darling: the chi-square test compares the observed frequencies with the frequencies of an assumed theoretical distribution (Ang and Tang, 1975).

5 The Kolmogorov-Smirnov test performs a comparison between the experimental cumulative frequency and an assumed theoretical distribution (Marsaglia et al., 2003). 
The Anderson-Darling test also compares the cumulative frequency, but it gives more weight to the tails (Anderson and Darling, 1954). The statistical fit analysis was performed with the software EasyFit 5.5 (http://www.mathwave.com/easyfit-distributionfitting.html).

5 Once the best fit distribution was selected, it was possible to associate probabilities to the computed values. It is important to note that even when the distribution function and the parameters of a given variable are known, we cannot predict with certainty the occurrence of a specific event; at best, we can say that the event will occur with an associated probability (Ang and Tang, 1975). Hence, it is important to specify the confidence interval. The most popular method for estimating interval limits is the pivotal $t$ statistic (Brownlee, 1960). However, such a method provides good confidence intervals for normally distributed population; the method may lead to wrong predictions for a population with a different distribution (Singh and Nocerino, 2002). Several studies analysed different methods for estimating confidence intervals for data with different probability distribution functions (Endo et al., 2009; Gutierrez et al., 2007; Wu et al., 2005; Takada and Nagata, 1995). The method used for the estimation of confidence interval was selected according to the results and will be explained in the respective section.

The glacier volume was estimated as the mean value of such a distribution. Then, 20 a trial and error approach was used in order to find the basal shear stress that provides a volume that fits the estimated mean glacier volume. Then, the estimated glacier thickness (GT) was subtracted from the glacier surface elevation (GSE) in order to get the glacier bed topography elevation (GBTE):

$\mathrm{GBTE}_{i, j}=\mathrm{GSE}_{i, j}-\mathrm{GT}_{i, j}$,

25 where the subscripts $i$ and $j$ identify the glacier cells according to their row and column in the raster. GSE was obtained from the DEM.
Probabilistic estimation of glacier volume and glacier bed topography

V. Moya Quiroga et al.

Title Page

Abstract Introduction

Conclusions

Tables

References

Figures

14

$>$ I

4

Back

$\triangleright$

Close

Full Screen / Esc

Printer-friendly Version

Interactive Discussion 


\section{Results and discussion}

The range of possible basal shear stress values is between $64.20 \mathrm{kPa}$ and $136.50 \mathrm{kPa}$. The value of $64.20 \mathrm{kPa}$ was denoted as basal shear stress $1(\tau 1)$, the value of $136.50 \mathrm{kPa}$ as basal shear stress $2(\tau 2)$, and the average value of $100.35 \mathrm{kPa}$ as basal 5 shear stress $3(\tau 3)$. Figure 3 shows a comparison of the distributed glacier thickness considering constant density and variable density, and the different basal shear stress considered. The value of the basal shear stress has a strong influence on the total volume estimation. The results using a basal shear stress of $64.20 \mathrm{kPa}$ are about half the value of the results using a basal shear stress of $136.50 \mathrm{kPa}$. Such results are not unexpected ones since $\tau 1$ is almost $50 \%$ of $\tau 2$, and the basal shear stress is directly proportional to the glacier thickness. The differences between the two density approaches are much lower. The variable density provides higher volume estimations. Such differences are expected since the variable density is lower than $900 \mathrm{~kg} \mathrm{~m}^{-3}$. Since glacier density is in the divisor of Eq. (1), lower densities will provide higher results. Considering variable density and $\tau 1$, the total volume is $10.5 \%$ higher than considering constant density and $\tau 1$. Considering variable density and $\tau 2$, the total volume is $3.3 \%$ higher than considering constant density and $\tau 2$. Considering variable density and $\tau 3$, the total volume is $3.9 \%$ higher than considering constant density and $\tau 3$. However, the uncertainties from glacier density are minor compared with the uncertainties from the basal shear stress. The biggest differences between a constant and a variable glacier density are in the spatial distribution of the glacier thickness. Figure 3 also shows that the area covered by low thickness is bigger when considering constant density. In all the cases the deepest part of the glacier is located at some $180 \mathrm{~m}$ from the east boundary. The deepest part is elongated with a north northeast-south southwest direction and a total longitude of $370 \mathrm{~m}$

The 34 methods provide different volume estimations (Table 2). The lowest estimation is provided by Bahr et al. (1997), and the highest is provided using the coefficients deduced from Francou et al. (2000). The average estimation is 0.027 , which is close to
Probabilistic estimation of glacier volume and glacier bed topography

V. Moya Quiroga et al.

Title Page
Abstract

Conclusions

Tables

14

4

Back
Introduction

References

Figures

$\rightarrow 1$

Close
Full Screen / Esc

Printer-friendly Version

Interactive Discussion 
the estimations according to Shiyin et al. (2003) and Macheret et al. (1984). However, such a mean value considers a simple normal average. After fitting the volume estimation to the different probability distribution functions (Table 3), it was found that the lognormal distribution is the one that has the best performance under the three best-fit 5 tests (Table 4). The gamma distribution is the one with the second-best performance. The distributions that ranked as the third and the fourth are the logistic distribution and the Weibull distribution. The normal distribution ranks as the fifth distribution. The worst performance is from the beta distribution and the exponential distribution.

Table 5 shows the mean and standard deviation (std) values of the different PDFs.

10 A superficial analysis of the result may lead to the idea that the differences are quite low. If we consider the lognormal mean value as the target value, the mean estimation from the beta distribution has the highest difference with an overestimation on $12.60 \%$. The Weibull distribution provides an underestimation of $3.96 \%$, and the other distributions have an overestimation about $0.25 \%$. However, the standard deviation shows much 15 higher differences. The beta distribution std is $37.28 \%$ higher, the Weibull std $15.78 \%$ lower, the exponential std almost three times higher, and the std from the other distributions $9.45 \%$ higher. Such differences have a strong influence over the confidence intervals. Considering the lognormal distribution the Huayna glacier has an estimated volume of $0.0275 \mathrm{~km}^{3}$. Such a volume is equivalent to a mean thickness of $24.98 \mathrm{~m}$. This volume can be obtained by considering a basal shear stress of $82.5 \mathrm{kPa}$.

It is important to point out that the US Environmental Protection Agency (EPA) performed an evaluation of different methods for the estimation of confidence intervals for data with different distributions (i.e. not normal distributed data) and suggested the use of different methods such as the Chebyshev approach (Singh et al., 2004). Actually, other studies also suggest the use of the Chebyshev approach for the estimation of confidence intervals of other distributions and unknown distributions (Amidan et al., 2005). The Chebyshev theorem tells us that, for any data set, the proportion of data (pd) that lies within $k$ standard deviation on either side of the mean is at least (Almukka-

Probabilistic

estimation of glacier

volume and glacier

bed topography

V. Moya Quiroga et al.

Title Page

Abstract

Introduction

Conclusions

References

Tables

Figures

14

$\Delta \mathbf{I}$

4

Back

$\checkmark$

Full Screen / Esc

Printer-friendly Version

Interactive Discussion 
hal et al., 2011)

$\mathrm{pd}=1-\frac{1}{k^{2}}$

Then, the upper confidence interval (UCl) and lower confidence interval (LCl) were obtained by adding and subtracting the respective confidence.

$5 \mathrm{UCl}=\bar{x}+k \frac{\sigma}{\sqrt{n}}=\bar{x}+$ Conf,

$\mathrm{LCI}=\bar{x}-k \frac{\sigma}{\sqrt{n}}=\bar{x}-$ Conf

where $n$ is the number of data values.

Table 6 shows the confidence values (Conf) to be added and subtracted in order to get the confidence interval for different probabilities.

Using the proper probability density function allows to obtain the cumulative distribution function (CDF) (Fig. 4), useful for estimating the probability that the variable, in this case the volume, is at least a given value. Models 11, 10,13 and 6 are within the $10 \%$ CDF; thus, there is a $90 \%$ probability that the glacier volume is higher than those 15 values. Models 27 and 1 are in the $20 \%$ CDF. Models 12, 33, 9, 28, 8 and 5 are in the $30 \%$ CDF. Models 30 and 26 are in the $40 \%$ CDF. Models 18, 17, 2 and 22 are in the $50 \%$ CDF. Models 15, 27 and 4 are in the $60 \%$ CDF. Models 14, 21, and 34 are in the $70 \%$ CDF. Models 19, 20, 31 and 23 are in the $80 \%$ CDF. Models 7 and 16 are in the $90 \%$ CDF. Models 33, 30, 2 and 24 have a CDF higher than $90 \%$. Model 24 may be considered as an outlier since it has a CDF higher than $90 \%$. This one is the only outlier.

Figure 5 shows the reconstructed glacier bed topography (GBT). The GBT shows the formation of a future lake in the quadrant D-3 once the glacier disappears. This lake has an area of $0.07 \mathrm{~km}^{2}$ and a maximum depth estimated of $32 \mathrm{~m}$. The areamaximum depth relation of the glacier is a reasonable value that fits reasonably with

Probabilistic estimation of glacier volume and glacier bed topography

V. Moya Quiroga et al.

Title Page

Abstract Introduction

Conclusions

Tables

References

Figures

14

$>$ I

4

Back

Close

Full Screen / Esc

Printer-friendly Version

Interactive Discussion 
other estimations. For instance, Sakai (2012) developed a power area-depth relation considering several glacial lakes. Applying such a relation to the present lake gives a maximum depth of $26.06 \mathrm{~m}$.

\section{Conclusions}

5 Theoretical approaches for glacier volume estimation are influenced by coefficients that depend on local conditions. They cannot predict with certainty the volume of a given glacier; however, they can predict the glacier volume with an associated probability. This study presented a comparison of different volume estimations and a statistical approach for predicting the associated probability of the estimated glacier volume. Besides, the influence of glacier density was evaluated.

The basal shear stress has a strong influence in estimation of the glacier thickness and glacier volume. The influence of the glacier depth is small compared with the influence of the basal shear stress influence for estimating the total glacier volume. Nevertheless, the glacier density has an important influence in the spatial distribution of the glacier thickness. Assuming a constant glacier density, the predicted glacier thickness is lower than the predicted assuming a variable glacier density, especially in lower areas.

The different glacier volume estimations are related by a lognormal probability distribution. The mean glacier volume is $0.0275 \mathrm{~km}^{3}$. Considering a $90 \%$ confidence level, such an estimation has an uncertainty of $0.0052 \mathrm{~km}^{3}$. The Huayna West glacier has a mean thickness of $24.98 \mathrm{~m}$. Considering a $90 \%$ confidence level, such an estimation has an uncertainty of $4.67 \mathrm{~m}$.

The mean glacier volume could be obtained assuming plastic behaviour and a basal shear stress of $82.50 \mathrm{kPa}$. This is a reasonable result since it is within the possible
Probabilistic estimation of glacier volume and glacier bed topography

V. Moya Quiroga et al.

Title Page

Abstract Introduction

Conclusions

Tables

References

Figures

14

$>$ I

4

Back

Close

Full Screen / Esc

Printer-friendly Version

Interactive Discussion 
The equations proposed by Macheret et al. (1984) and Shiyin et al. (2003) provide the nearest estimation to the mean glacier volume. The glacier volume estimated with the GlabTop approach considering basal shear stress of $64.20 \mathrm{kPa}$ and variable glacier density is the closest to the lower confidence interval. This estimation has a cumulative 5 distribution function (CDF) of $35 \%$. The glacier volume estimated with the GlabTop approach considering a basal shear stress of $100.35 \mathrm{kPa}$ and variable glacier density is the closest to the upper confidence interval. This estimation has a cumulative distribution function (CDF) of $73 \%$.

Glacier bed topography showed the formation of a future glacial lake. The estimated 10 area and depth of this lake have a reasonable agreement with dimensions observed at other glacial lakes.

Glacier retreat will not only influence the water availability, but also induce morphometric changes to the hydrological drainage network.

Acknowledgements. The authors would like to thank the Science and Technology Research 15 Partnership for Sustainable Development (SATREPS) of Japan Science and Technology Agent - Japan International Cooperation Agency (JST-JICA). This research was developed within the framework of the GRANDE project, financed by SATREPS

\section{References}

Adhikari, S. and Marshall, S. J.: Glacier volume-area relation for high-order mechanics and transient glacier states, Geophys. Res. Lett., 39, 1-6, doi:10.1029/2012GL052712, 2012.

Almukkahal, R., DeLancey, D., Lawsky, E., Meery, B., and Ottman, L.: CK-12 Advanced Probability and Statistics, 2nd Edn., available at: http://www.switzerland.k12.in.us/pdf/ Digital\%20textbooks/CK_12_Advanced_Probability_and_Statistics_Second_Edition.pdf (last access: 1 July 2013), 2011.

25 Amidan, B. G., Ferryman, T. B., and Cooley, S. K.: Data outlier detection using the Chebyshev theorem, 2005 IEEE Aerospace Conference, 3814-3819, doi:10.1109/AERO.2005.1559688, 2005.
Probabilistic estimation of glacier volume and glacier bed topography

V. Moya Quiroga et al.

Title Page
Abstract

Conclusions

Tables

14

4

Back
Introduction

References

Figures

$>1$

$\checkmark$

Close
Full Screen / Esc

Printer-friendly Version

Interactive Discussion 
Anderson, T. W. and Darling, D. A.: A test of goodness fit, J. Am. Stat. Assoc., 49, 765-769, doi:10.1080/01621459.1954.10501232, 1954

Andreassen, L. M., Kjøllmoen, B., Rasmussen, A., Melvold, K., and Nordli, Ø.: Langfjordjøkelen, a rapidly shrinking glacier in northern Norway, J. Glaciol., 58, 581-593, doi:10.3189/2012JoG11J014, 2012.

Ang, A. H.-S. and Tang, W. H.: Probability Concepts in Engineering, Planning and Design, vol. 1, 2nd edn., John Wiley and Sons, New York, 1975.

Bælum, K. and Benn, D. I.: Thermal structure and drainage system of a small valley glacier (Tellbreen, Svalbard), investigated by ground penetrating radar, The Cryosphere, 5, 139$10 \quad$ 149, doi:10.5194/tc-5-139-2011, 2011.

Bahr, D. B.: Global distributions of glacier properties: a stochastic scaling paradigm, Water Res., 33, 1669-1679, doi:10.1029/97WR00824, 1997.

Bahr, D. B., Meier, M. F., and Peckham, S. D.: The physical basis of glacier volume-area scaling, J. Geophys. Res., 102, 20355-20362, doi:10.1029/97JB01696, 1997.

15 Bamber, J. L., Gomez-Dans, J. L., and Griggs, J. A.: A new $1 \mathrm{~km}$ digital elevation model of the Antarctic derived from combined satellite radar and laser data - Part 1: Data and methods, The Cryosphere, 3, 101-111, doi:10.5194/tc-3-101-2009, 2009.

Bamber, J. L., Griggs, J. A., Hurkmans, R. T. W. L., Dowdeswell, J. A., Gogineni, S. P., Howat, I., Mouginot, J., Paden, J., Palmer, S., Rignot, E., and Steinhage, D.: A new bed elevation dataset for Greenland, The Cryosphere, 7, 499-510, doi:10.5194/tc-7-499-2013, 2013.

Baraer, M., Mark, B., McKenzie, J., Condom, T., Bury, J., Huh, K.-I., Portocarrero, C., Gomez, J., and Rathay, S.: Glacier recession and water resources in Peru's Cordillera Blanca, J. Glaciol., 58, 134-150, doi:10.3189/2012JoG11J186, 2012.

Binaghi, E., Pedoia, V., Guidali, A., and Guglielmin, M.: Snow cover thickness estimation using radial basis function networks, The Cryosphere, 7, 841-854, doi:10.5194/tc-7-841-2013, 2013.

Binder, D., Brückl, E., Roch, K. H., Behm, M., Schöner, W., and Hynek, B.: Determination of total volume and ice-thickness distribution of two glaciers in the Hohe Tauern region, Eastern Alps, from GPR data, Ann. Glaciol., 50, 71-79, doi:10.3189/172756409789097522, 2009.

30 Bodin, X., Rojas, F., and Brenning, A.: Status and evolution of the cryosphere in the Andes of Santiago (Chile, 33.5 S), Geomorphology, 118, 453-464, doi:10.1016/j.geomorph.2010.02.016, 2010.

Probabilistic

estimation of glacier

volume and glacier

bed topography

V. Moya Quiroga et al.

Title Page

Abstract

Conclusions

Tables

14

4

Back

Full Screen / Esc

Printer-friendly Version 
Brownlee, K. A.: Statistical Theory and Methodology in Science and Engineering, Wiley and Sons, New York, 1960.

Calvo, N., Durany, J., and Vázquez, C.: A new fully nonisothermal coupled model for the simulation of ice sheet flow, Physica D, 239, 248-257, doi:10.1016/j.physd.2009.11.003, 2010.

5 Chen, J. and Ohmura, A.: Estimation of Alpine glacier water resources and their change since 1870's, IAHS-AISH P., 193, 127-135, 1990.

Clarke, G. K. C., Berthier, E., Schoof, C. G., and Jarosch, A. H.: Neural networks applied to estimating subglacial topography and glacier volume, J. Climate, 22, 2146-2160, doi:10.1175/2008JCLI2572.1, 2009.

10 Clarke, G. K. C., Anslow, F., Jarosch, A., Radic, V., Menounos, B., Bolch, T., and Berthier, E.: Ice volume and subglacial topography for western Canadian glaciers from mass balance fields, thinning rates, and a bed stress model, J. Climate, 26, 4282-4303, doi:10.1175/JCLI-D-1200513.1, 2013.

Colgan, W., Pfeffer, W. T., Rajaram, H., Abdalati, W., and Balog, J.: Monte Carlo ice flow modeling projects a new stable configuration for Columbia Glacier, Alaska, c. 2020, The Cryosphere, 6, 1395-1409, doi:10.5194/tc-6-1395-2012, 2012.

Condom, T., Coudrain, A., Sicart, J. E., and Thery, S.: Computation of the space and time evolution of equilibrium-line altitudes on Andean glaciers $\left(10^{\circ} \mathrm{N}-55^{\circ} \mathrm{S}\right)$, Global Planet. Change, 59, 189-202, doi:10.1016/j.gloplacha.2006.11.021, 2007.

20 Cooper, A. P. R., Tate, J. W., and Cook, A. J.: Estimating ice thickness in South Georgia from SRTM elevation data, in: Joint International Conference on Theory, Data Handling and Modelling in GeoSpatial Information Science, ISPRS archives, 38 (part 2), Hong Kong, 26-28 May, 592-597, 2010.

Crooks, S.: The effect of sea-level rise on coastal geomorphology, Ibis, 149, 18-20, 2004.

Cuffey, K. M. and Paterson, W. S. B.: The Physics of Glaciers, 4th edn., ButterworthHeinemann/Elsevier, Amsterdam, the Netherlands, 2010.

Debolskaya, E. I. and Isaenkov, A. Y.: Mathematical modeling of the transportation competency of an ice-covered flow, Water Resour., 37, 653-661, doi:10.1134/S0097807810050052, 2010.

30 Degenhardt, J. J.: Development of tongue-shaped and multilobate rock glaciers in alpine environments - interpretations from ground penetrating radar surveys. Geomorphology, 109, 94-107, doi:10.1016/j.geomorph.2009.02.020, 2009.

Probabilistic

estimation of glacier

volume and glacier

bed topography

V. Moya Quiroga et al.

Title Page

Abstract

Introduction

Conclusions

References

Tables

Figures

14

$\Delta \mathbf{I}$

4

Back

$\checkmark$

Close

Full Screen / Esc

Printer-friendly Version

Interactive Discussion 
Dissanayake, D. M. P. K., Ranasinghe, R., and Roelvik, J. A.: Effect of sea level rise in tidal inlet evolution: A numerical modelling approach, J. Coast. Res., Special Issue 56, 942-946, 2009.

Dowdeswell, J. A. and Evans, S.: Investigations of the form and flow of ice sheets and glaciers using radio-echo sounding, Rep. Prog. Phys., 67, 1821-1861, doi:10.1088/00344885/67/10/R03, 2004.

Driedger, C. L. and Kennard, P. M.: Ice Volumes on Cascade Volcanoes: Mount Rainer, Mount Hood, Three Sisters, Mount Shasta, Available from Supt Doc, USGPO, Wash DC 20402, USGS Professional Paper 1365, 28 pp., 1986.

10 Dundar, M. and Landgrebe, D.: A cost-effective semisupervised classifier approach with kernels, IEEE T. Geosci. Remote, 42, 264-270, 2004.

Dyurgerov, M. and Meier, M. F.: Glaciers and the Changing Earth System: a 2004 snapshot, Occasional Paper 58, Institute of Arctic and Alpine Research, University of Colorado, Boulder, CO, 118 pp., 2005.

Endo, Y.: Estimate of confidence intervals for geometric mean diameter and geometric standard deviation of lognormal size distribution, Powder Technol., 193, 154-161, doi:10.1016/j.powtec.2008.12.019, 2009.

Erasov, N. V.: Method to determine the volume of mountain glaciers (in Russian), Mater, Glyatsiol, Issled, Khronika, Obsuzhdniya, 14, 307-308, 1968.

20 Farinotti, D., Huss, M., Bauder, A., and Funk, M.: An estimate of the glacier volume in the Swiss Alps, Global Planet. Change, 68, 225-231, doi:10.1016/j.gloplacha.2009.05.004 2009.

Farinotti, D., Corr, H., and Gudmundsson, G. H.: The ice thickness distribution of Flask Glacier, Antarctic Peninsula, determined by combining radio-echo soundings, surface velocity data and flow modelling, Ann. Glaciol., 54, 18-24, doi:10.3189/2013AoG63A603, 2013.

Francou, B., Ramirez, E., Caceres, B., and Mendoza, J.: Glacier evolution in the tropical Andes during the last decades of the 20th century: Chacaltaya, Bolivia and Antizana, Ecuador, Ambio, 29, 416-422, doi:10.1579/0044-7447-29.7.416, 2000.

Frey, H., Haeberli, W., Linsbauer, A., Huggel, C., and Paul, F.: A multi-level strategy for anticipating future glacier lake formation and associated hazard potentials, Nat. Hazards Earth $30 \quad$ Syst. Sci., 10, 339-352, doi:10.5194/nhess-10-339-2010, 2010.

Ginot, P.: Glaciochemical study of ice cores from Andean glaciers, Ph.D. thesis, Inauguraldissertation der Philosophisch-naturwissenschaftlichen Fakultät der Universität Bern, Bern, Switzerland, 185 pp., 2001.
Probabilistic

estimation of glacier

volume and glacier

bed topography

V. Moya Quiroga et al.

Title Page
Abstract

Conclusions

14

4

Back
Tables
Introduction

References

Figures

$\Delta$

$>$

Close
Full Screen / Esc

Printer-friendly Version

Interactive Discussion 
Gleick, P. H.: Water resources, in: Encyclopedia of Climate and Weather, vol. 2, edited by: Schneider, S. H., Oxford University Press, New York, 817-823, 1996.

Goldberg, D. N. and Sergienko, O. V.: Data assimilation using a hybrid ice flow model, The Cryosphere, 5, 315-327, doi:10.5194/tc-5-315-2011, 2011.

5 Goodman, R. H.: Radio echo sounding on temperate glaciers, J. Glaciol., 14, 37-69, 1975.

Grinsted, A.: An estimate of global glacier volume, The Cryosphere, 7, 141-151, doi:10.5194/tc7-141-2013, 2013.

Gutiérrez, R., Rico, N., Román, P., and Torres, F.: Approximate and generalized confidence bands for the mean and mode functions of the lognormal diffusion process, Comput. Stat.

10 Data An., 51, 4038-4053, doi:10.1016/j.csda.2006.12.027, 2007.

Haeberli, W. and Hoelzle, M.: Application of inventory data for estimating characteristics and regional climate-change effects on mountain glaciers: a pilot study in the European Alps, Ann. Glaciol., 21, 206-212, 1995.

Hoelzle, M., Chinn, T., Stumm, D., Paul, F., Zemp, M., and Haeberli, W.: The application of glacier inventory data for estimating past climate change effects on mountain glaciers: a comparison between the European Alps and the Southern Alps of New Zealand, Global Planet. Change, 56, 69-82, doi:10.1016/j.gloplacha.2006.07.001, 2007.

Huss, M.: Density assumptions for converting geodetic glacier volume change to mass change, The Cryosphere, 7, 877-887, doi:10.5194/tc-7-877-2013, 2013.

Huss, M. and Farinotti, D.: Distributed ice thickness and volume of all glaciers around the globe, J. Geophys. Res., 117, 1-10, doi:10.1029/2012JF002523, 2012.

Huss, M., Farinotti, D., Bauder, A., and Funk, M.: Modelling runoff from highly glacierized alpine drainage basins in a changing climate, Hydrol. Process., 22, 3888-3902, doi:1002/hyp.7055, 2008.

Huss, M., Jouvet, G., Farinotti, D., and Bauder, A.: Future high-mountain hydrology: a new parameterization of glacier retreat, Hydrol. Earth Syst. Sci., 14, 815-829, doi:10.5194/hess14-815-2010, 2010.

Jacobell, R. W., Lapo, K. E., Stamp, J. R., Youngblood, B. W., Welch, B. C., and Bamber, J. L.: A comparison of basal reflectivity and ice velocity in East Antarctica, The Cryosphere, 4, 447-452, doi:10.5194/tc-4-447-2010, 2010.

Johanesson, T.: A simple (simplistic) method to include glaciated areas with a limited ice volume in the WaSiM and HBV models, Icelandic Met Office, ÚR-TóJ-2009-01, 1-3, 2009.

Probabilistic

estimation of glacier

volume and glacier

bed topography

V. Moya Quiroga et al.

Title Page

Abstract

Introduction

Conclusions

Tables

References

Figures

14

$\Delta \mathbf{I}$

4

Back

$\triangleright$

Close

Full Screen / Esc

Printer-friendly Version

Interactive Discussion 
Kääb, A.: Photogrammetric reconstruction of glacier mass-balance using a kinematic ice-flow model, a 20-year time-series on Grubengletscher, Swiss Alps, Ann. Glaciol., 31, 45-52, doi:10.3189/172756400781819978, 2000.

Kaser, G., Hardy, D. R., Molg, T., Bradley, R. S., and Hyera, T. M.: Moder glacier retreat on $5 \quad$ Kilimanjaro as evidence of climate change: observation and facts, Int. J. Climatol., 24, 329339, doi:10.1002/joc.1008, 2004.

Kaser, G., Grosshauser, M., and Marzeion, B.: Contribution potential of glaciers to water availability in different climate regimes, P. Natl. Acad. Sci. USA, 107, 1-5, doi:10.1073/pnas.1008162107, 2010.

10 Kavanaugh, J. L. and Clarke, G. K. C.: Discrimination of the flow law for subglacial sediment using in situ measurements and an interpretation model, J. Geophys. Res., 111, 120, doi:10.1029/2005JF000346, 2006.

Klein, A. G. and Isacks, B. L.: Alpine glacial geomorphological studies in the central Andes using Landsat thematic mapper images, Glacial Geology and Geomorphology, rp01/1998, 1998.

Komori, J., Koike, T., Yamanokuchi, T., and Tshering, P.: Glacial lake outburst events in the Buthan Himalayas, Global Environ. Res., 16, 59-70, 2012.

Landgrebe, D.: Multispectral land sensing: where from, where to?, IEEE T. Geosci. Remote, 43, 414-421, 2005.

20 Lee, J., Kim, K. Y., Hong, J. K., and Jin, Y. K.: An englacial image and water pathways of the fourcade glacier on King George Island, Antarctic Peninsula, inferred from ground-penetrating radar, Sci. China Earth Sci., 53, 892-900, doi:10.1007/s11430-010-0078-z, 2010.

Lenaerts, J. T. M., van Angelen, J. H., van den Broeke, M. R., Gardner, A. S., Wouters, B., and van Meijgaard, E.: Irreversible mass loss of Canadian Arctic Archipelago glaciers, Geophys. Res. Lett., 40, 870-874, doi:10.1002/grl.50214, 2013.

Li, H., Ng, F., Li, Z., Qin, D., and Cheng, G.: An extended "perfect-plasticity" method for estimating ice thickness along the flow line of mountain glaciers, J. Geophys. Res., 117, 1-11, doi:10.1029/2011JF002104, 2012.

Linsbauer, A., Paul, F., and Haeberli, W.: Modeling glacier thickness distribution and bed topog30 raphy over entire mountain ranges with GlabTop: application of a fast and robust approach, J. Geophys. Res., 117, 1-17, doi:10.1029/2011JF002313, 2012.
Probabilistic estimation of glacier volume and glacier bed topography

V. Moya Quiroga et al.

Title Page
Abstract

Conclusions

Tables

14

4

Back
Introduction

References

Figures

$\Delta$

$>$

Close
Full Screen / Esc

Printer-friendly Version

Interactive Discussion 
Liu, S., Sun, W., Shen, Y., and Li, G.: Glacier changes since the Little Ice Age maximum in the western Qilian Shan, northwest China, and consequences of glacier runoff for water supply, J. Glaciol., 49, 117-124, 2003.

Macheret, Y. Y., Zhuravlev, A. B., and Bobrova, L. I.: Thickness, subglacial topography and 5 volume of Svalbard glaciers from radio echo-sounding data, Data of glaciological studies, 51, 59-62, 1984 (in Russian).

Macheret, Y. Y., Cherkasov, P. A., and Bobrova, L. I.: Thickness and volume of glaciers in the Dzungarian Alatau from airborne radio-echo sounding, Data of glaciological studies, 62, 5971, 1988 (in Russian).

10 Marsaglia, G., Tsang, W. W., and Wang, J.: Evaluating Kolmogorov's distribution, J. Stat. Softw., 8, 1-4, 2003.

Meier, M. F. and Bahr, D. B.: Counting Glaciers: Use of Scaling Methods to Estimate the Number and Size Distribution of the Glaciers in the World, edited by: Hanover, N. H., CRREL Spec. Rep., US Army, 89-95, 1996.

Michel, L., Picasso, M., Farinotti, D., Bauder, A., Funk, M., and Blatter, H: Estimating the ice thickness of mountain glaciers with an inverse approach using surface topography and massbalance, Inverse Probl., 29, 1-23, doi:10.1088/0266-5611/29/3/035002, 2013.

Monnier, S., Camerlynck, C., Rejiba, F., Kinnard, C., Feuillet, T., and Dhemaied, A.: Structure and genesis of the Thabor rock glacier (Northern French Alps) determined from morphological and ground-penetrating radar surveys, Geomorphology, 134, 269-279, doi:10.1016/j.geomorph.2011.07.004, 2011.

Morlighem, M., Rignot, E., Seroussi, H., Larour, E., Ben Dhia, H., and Aubry, D.: A mass conservation approach for mapping glacier ice thickness, Geophys. Res. Lett., 38, 1-6, doi:10.1029/2011GL048659, 2011.

Mote, P. W. and Kaser, G.: The shrinking glaciers of Kilimanjaro: can global warming be blamed? A "poster child" for climate change starves for snow and sublimates, Am. Sci., 95, 318-325, doi:10.1511/2007.66.3752, 2007.

Naito, N., Suzuki, R., Komori, J., Matsuda, Y., Yamaguchi, S., Sawagaki, T., Tshering, P., and Ghalley, K. S.: Recent glacier shrinkages in the laguna region, Buthan Himalayas, Global $30 \quad$ Environ. Res., 16, 13-22, 2012.

Navarro, F. J., Macheret, Y. Y., and Benjumea, B.: Application of radar and seismic methods for the investigation of temperate glaciers, J. Appl. Geophys., 57, 193-211, doi:10.1016/j.jappgeo.2004.11.002, 2005.

Probabilistic

estimation of glacier

volume and glacier

bed topography

V. Moya Quiroga et al.

Title Page

Abstract

Introduction

Conclusions

Tables

References

Figures

14

$>$ I

4

Back

Close

Full Screen / Esc

Printer-friendly Version

Interactive Discussion 
Nicholson, L., Marin, J., Lopez, D., Rabatel, A., Bown, F., and Rivera, A.: Glacier inventory of the upper Huasco valley, Norte Chico, Chile: glacier characteristics, glacier change and comparison with central Chile, Ann. Glaciol., 50, 111-118, doi:10.3189/172756410790595787, 2009.

5 Nye, J. F.: A comparison between the theoretical and measured long profile of the unteraar glacier, J. Glaciol., 2, 103-107, 1954.

Nye, J. F.: Plasticity solution for a glacier snout, J. Glaciol., 6, 695-715, 1967.

Ohara, N., Jang, S., Kure, S., Chen, Z. Q., and Kavvas, M. L.: Modeling of interannual snow and ice storage in high altitude region by dynamic equilibrium concept, J. Hydrol. Eng., in press, 2013.

Paul, F., Kääb, A., and Haeberli, W.: Recent glacier changes in the Alps observed by satellite: consequences for future monitoring strategies, Global Planet. Change, 56, 111-122, doi:10.1016/j.gloplacha.2006.07.007, 2007.

Paul, F. and Linsbauer, A.: Modeling of glacier bed topography from glacier outlines, central 15 branch lines, and DEM, Int. J. Geogr. Inf. Sci., 26, 1173-1190, 2012.

Peduzzi, P., Herold, C., and Silverio, W.: Assessing high altitude glacier thickness, volume and area changes using field, GIS and remote sensing techniques: the case of Nevado Coropuna (Peru), The Cryosphere, 4, 313-323, doi:10.5194/tc-4-313-2010, 2010.

Radic, V. and Hock, R.: Regional and global volumes of glaciers derived from statistical upscaling of glacier inventory data, J. Geophys. Res., 115, 1-10, doi:10.1029/2009JF001373, 2010.

Radic, V., Hock, R., and Oerlemans, J.: Volume-area scaling vs flowline modelling in glacier volume projections, Ann. Glaciol., 46, 234-240, doi:10.3189/172756407782871288, 2007.

Radic, V., Hock, R., and Oerlemans, J.: Analysis of scaling methods in deriving future volume evolutions of valley glaciers, J. Glaciol., 54, 601-612, doi:10.3189/002214308786570809, 2008.

Ramirez, E., Francou, B., Ribstein, P., Descloitres, M., Guerin, R., Mendoza, J., Gallaire, R., Poyaud, B., and Jordan, E.: Small glaciers dissapearing in the tropical Andes: a case-study in Bolivia: glaciar Chacaltaya $\left(16^{\circ} \mathrm{S}\right)$, J. Glaciol., 47, 187-194, doi:10.3189/172756501781832214, 2001.

Raper, S. C. B. and Braithwaite, R. J.: Low sea level rise projections from mountain glaciers and icecaps under global warming, Nature, 439, 311-313, doi:10.1038/nature04448, 2006.

Probabilistic

estimation of glacier

volume and glacier

bed topography

V. Moya Quiroga et al.

Title Page

Abstract

Introduction

Conclusions

References

Tables

Figures

14

$\Delta \mathbf{I}$

4

Back

$\checkmark$

Full Screen / Esc

Printer-friendly Version

Interactive Discussion 
Raup, B. H., Racoviteanu, A., Khalsa, S. J. S., Helm, C., Armstrong, R., and Arnaud, Y.: The GLIMS Geospatial Glacier Database: a new tool for studying glacier change, Global Planet. Change, 56, 101-110, doi:10.1016/j.gloplacha.2006.07.018, 2007.

Ren, D., Leslie, L. M., and Lynch, M. J.: Verification of model simulated mass balance, flow fields and tabular calving events of the Antarctic ice sheet against remotely sensed observations, Clim. Dynam., 40, 2617-2636, doi:10.1007/s00382-012-1464-3, 2012.

Rignot, E. J.: Fast recession of a West Antarctic glacier, Science, 281, 549-551, 1998.

Sakai, A.: Glacial lakes in the Himalayas: a review on formation and expansion processes, Global Environ. Res., 16, 23-30, 2012.

10 Sawagaki, T., Lamsal, D., Byers, A. C., and Watanabe, T.: Changes in surface morphology and glacial lake development of Chamlang South Glacier in the Eastern Nepal Himalaya since 1964, Global Environ. Res., 16, 84-94, 2012.

Scharrer, K., Spieler, O., Mayer, C., and Münzer, U.: Imprints of sub-glacial volcanic activity on a glacier surface - SAR study of Katla volcano, Iceland, B. Volcanol., 70, 495-506, doi:10.1007/s00445-007-0164-z, 2008.

Shumsky, P. A.: Density of glacier ice, J. Glaciol., 3, 568-573, 1959.

Singh, A. and Nocerino, J. M.: Robust estimation of mean and variance using environmental data sets with below detection limit observations, Chemometr. Intell. Lab., 60, 69-86, 2002.

Singh, A. K., Singh, A., and Engelhardt, M.: Technology Support Center Issue The Lognormal Distribution in Environmental Applications, Technology Support Center Issue, Environmental Protection Agency, 1-20, 2004.

Singh, K. K., Kulkarni, A. V., and Mishra, V. D.: Estimation of glacier depth and moraine cover study using Ground Penetrating Radar (GPR) in the Himalayan region, J. Indian Soc. Remote Sens., 38, 1-9, 2010.

Sørensen, L. S., Simonsen, S. B., Nielsen, K., Lucas-Picher, P., Spada, G., Adalgeirsdottir, G., Forsberg, R., and Hvidberg, C. S.: Mass balance of the Greenland ice sheet (2003-2008) from ICESat data - the impact of interpolation, sampling and firn density, The Cryosphere, 5, 173-186, doi:10.5194/tc-5-173-2011, 2011.

Surazakov, A. B. and Aizen, V. B.: Estimating volume change of mountain glaciers using SRTM and map-based topographic data, IEEE T. Geosci. Remote, 44, 2991-2995, 2006.

Tadono, T., Kawamoto, S., Narama, C., Yamanokuchi, T., Ukita, J., Tomiyama, N., and Yabuki, $\mathrm{H}$.: Development and validation of new glacial lake inventory in the Buthan Himalayas using ALOS "DAICHI", Global Environ. Res., 16, 31-40, 2012.

Probabilistic

estimation of glacier

volume and glacier

bed topography

V. Moya Quiroga et al.

Title Page

Abstract

Introduction

Conclusions

References

Tables

Figures

14

$\Delta \mathbf{I}$

4

Back

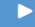

Full Screen / Esc

Printer-friendly Version

Interactive Discussion 
Takada, Y. and Nagata, Y.: Fixed-width sequential confidence interval the mean of a gamma distribution, J. Stat. Plan. Infer., 44, 277-289, 1995.

Tarboton, D. G.: A new method for the determination of flow directions and upslope areas in grid digital elevation models, Water Resour. Res., 33, 309-319, doi:10.1029/96WR03137, 1997.

Thoma, M., Grosfeld, K., Mayer, C., and Pattyn, F.: Interaction between ice sheet dynamics and subglacial lake circulation: a coupled modelling approach, The Cryosphere, 4, 1-12, doi:10.5194/tc-4-1-2010, 2010.

Uchupi, E., Driscoll, N., Ballard, R. D., and Bolmer, S. T.: Drainage of late Wisconsin glacial lakes and the morphology and late quaternary stratigraphy of the New Jersey-southern New England continental shelf and slope, Mar. Geol., 172, 117-145, doi:10.1016/S00253227(00)00106-7, 2001.

Van de Wal, R. S. W. and Wild, M.: Modelling the response of glaciers to climate change by applying volume-area scaling in combination with a high resolution GCM, Clim. Dynam., 18, 15 359-366, 2001.

Vuille, M., Francou, B., Wagnon, P., Juen, I., Kaser, G., Mark, B. G., and Bradley, R. S.: Climate change and tropical Andean glaciers: past, present and future, Earth-Sci. Rev., 89, 79-96, doi:10.1016/j.earscirev.2008.04.002, 2008.

Wang, X., Jiang, Z., Zhang, A., Zhou, Z., and An, J.: Two-phase flow numerical simulation of a bend-type ice sluice in the diversion water channel of powerhouse, Cold Reg. Sci. Technol., 81, 36-47, doi:10.1016/j.coldregions.2012.02.004, 2012.

Wu, J., Wong, A. C. M., and Ng, K. W.: Likelihood-based confidence interval for the ratio of scale parameters of two independent Weibull distributions, J. Stat. Plan. Infer., 135, 487497, doi:10.1016/j.jspi.2004.05.012, 2005.

Yafeng, S., Zongtai, W., and Chaohai, L.: Note on the glacier inventory in Qilian Shan Mountains, in: Glacier Inventory of China, 1, Qilian Mountains, Lanzhou, Institution of Glaciology and Geocryology, 1-9, 1981.

Zekollari, H., Huybrechts, P., Fürst, J. J., Rybak, O., and Eisen, O.: Calibration of a higher-order 3-D ice-flow model of the Morteratsch glacier complex, Engadin, Switzerland, Ann. Glaciol., $30 \quad$ 54, 343-351, doi:10.3189/2013AoG63A434, 2013.

Zhuravlev, A. V.: The relation between glacier area and volume, in: Data of Glaciological Studies, vol. 40, edited by: Avsyuk, G. A. and Balkema, A. A., Rotterdam, The Netherlands, Russ. Transl. Ser., 67, 441-446, 1988.

Probabilistic

estimation of glacier

volume and glacier

bed topography

V. Moya Quiroga et al.

Title Page

Abstract

Introduction

Conclusions

Tables

References

Figures

14

4

Back

Close

Full Screen / Esc

Printer-friendly Version

Interactive Discussion 
Table 1. Methods used for the estimation of the glacier volume. Methods from group "a" estimate glacier volume. Methods from group "b" estimate mean glacier thickness. Methods from group "c" estimate the glacier thickness of the flow lines according to Eq. (1). In group "c", $\tau 1$ considers a basal shear stress of $64.2 \mathrm{kPa}, \tau 2$ a basal shear stress of $136.50 \mathrm{kPa}$ and $\tau 3$ a basal shear stress of $100.35 \mathrm{kPa}$. Suffix a considers variable glacier density (Eq. 6), and suffix b considers constant density $\left(900 \mathrm{~kg} \mathrm{~m}^{-3}\right)$. The estimation $2\left(^{*}\right)$ is defined by the shape. The estimation $3\left(^{* *}\right)$ is defined by the slope. Estimation $12\left(^{* * *}\right)$ is for glaciers smaller than $25 \mathrm{~km}^{2}$.

\begin{tabular}{lllclll}
\hline Group & Estimation & Method & Output & Input & $c$ & $\gamma$ \\
\hline a & 1 & Adhikari and Marshall (2012) & $V$ & $A$ & 0.048 & 1.1439 \\
a & 2 & Adhikari and Marshall (2012)* & $V$ & $A$ & 0.0353 & 1.328 \\
a & 3 & Adhikari and Marshall (2012)** & $V$ & $A$ & 0.0336 & 1.3835 \\
a & 4 & Bahr (1997) & $V$ & $A$ & 0.02 & 1.375 \\
a & 5 & Bahr et al. (1997) & $V$ & $A$ & 0.0276 & 1.36 \\
a & 6 & Baraer et al. (2012) & $V$ & $A$ & 0.04088 & 1.375 \\
a & 7 & Chen and Ohmura (1990) & $V$ & $A$ & 0.0285 & 1.357 \\
a & 8 & Driedger and Kennard (1986) & $V$ & $A$ & 0.0218 & 1.124 \\
a & 9 & Erasov (1968) & $V$ & $A$ & 0.027 & 1.5 \\
a & 10 & Francou et al. (2000) & $V$ & $A$ & 0.1091 & 2.0207 \\
a & 11 & Grinsted (2013) & $V$ & $A$ & 0.0433 & 1.29 \\
a & 12 & Grinsted (2013) & $V$ & $A$ & 0.0435 & 1.23 \\
a & 13 & Johanesson (2009) & $V$ & $A$ & 0.036 & 1.36 \\
a & 14 & Klein and Isacks (1998) & $V$ & $A$ & 0.048 & 1.36 \\
a & 15 & Liu et al. (2003) & $V$ & $A$ & 0.04 & 1.35 \\
a & 16 & Macheret and Zhuravlev (1982) & $V$ & $A$ & 0.0597 & 1.12 \\
a & 17 & Macheret et al. (1984) & $V$ & $A$ & 0.0371 & 1.357 \\
a & 18 & Macheret et al. (1988) & $V$ & $A$ & 0.0298 & 1.379 \\
a & 19 & Meier and Bahr (1996) & $V$ & $A$ & 0.02 & 1.36 \\
a & 20 & Radic and Hock (2010) & $V$ & $A$ & 0.0365 & 1.375 \\
a & 21 & Van de Wal and Wild (2001) & $V$ & $A$ & 0.0213 & 1.375 \\
a & 22 & Yafeng (1981) & $V$ & $A$ & 0.0361 & 1.406 \\
a & 23 & Zhuravlev (1985) & $V$ & $A$ & 0.03 & 1.36 \\
a & 24 & Zhuravlev (1988) & $V$ & $A$ & 0.048 & 1.186 \\
b & 25 & Bodin et al. (2010) & $\bar{h}$ & $A$ & 28.5 & 0.357 \\
b & 26 & Huss and Farinotti (2012) & $\bar{h}$ & $A$ & 32.7 & 0.31 \\
b & 27 & Nicholson et al. (2009) & $\bar{h}$ & $A$ & 39.09 & 0.6009 \\
b & 28 & Ohara et al. (2013) & $\bar{h}$ & $A$ & 24.625 & 0.3334 \\
c & 29 & $\tau 1 a$ & $h$ & $\tau, \alpha, \rho$ & n.a. & n.a. \\
c & 30 & $\tau 1 b$ & $h$ & $\tau, \alpha, \rho$ & n.a. & n.a. \\
c & 31 & $\tau 2 a$ & $h$ & $\tau, \alpha, \rho$ & n.a. & n.a. \\
c & 32 & $\tau 2 b$ & $h$ & $\tau, \alpha, \rho$ & n.a. & n.a. \\
c & 33 & $\tau 3 a$ & $h$ & $\tau, \alpha, \rho$ & n.a. & n.a. \\
c & 34 & $\tau 3 b$ & n.a. & n.a. \\
\hline & & & & & & \\
\hline
\end{tabular}

7, 3931-3967, 2013

Probabilistic

estimation of glacier

volume and glacier

bed topography

V. Moya Quiroga et al.

Title Page

Abstract

Introduction

Conclusions

References

Tables

Figures

14

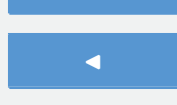

$>$ I

Back

Close

Full Screen / Esc

Printer-friendly Version

Interactive Discussion 
Table 2. Glacier volume estimations.

\begin{tabular}{|c|c|c|c|c|}
\hline Group & Estimation & Equation & $V\left(\mathrm{~km}^{3}\right)$ & $\bar{h}(\mathrm{~m})$ \\
\hline a & 1 & Adhikari and Marshall (2012) & 0.0363 & 46.33 \\
\hline a & 2 & Adhikari and Marshall (2012) ${ }^{*}$ & 0.0255 & 32.57 \\
\hline a & 3 & Adhikari and Marshall (2012) ${ }^{* *}$ & 0.0239 & 30.58 \\
\hline a & 4 & Bahr (1997) & 0.0142 & 18.24 \\
\hline a & 5 & Bahr et al. (1997) & 0.0197 & 25.27 \\
\hline a & 6 & Baraer et al. (2012) & 0.0291 & 37.29 \\
\hline a & 7 & Chen and Ohmura (1990) & 0.0204 & 26.11 \\
\hline a & 8 & Driedger and Kennard (1986) & 0.0165 & 21.14 \\
\hline a & 9 & Erasov (1968) & 0.0187 & 23.89 \\
\hline a & 10 & Francou et al. (2000) & 0.0665 & 84.98 \\
\hline a & 11 & Grinsted (2013) & 0.0315 & 40.33 \\
\hline a & 12 & Grinsted $(2013)^{* * *}$ & 0.0321 & 41.11 \\
\hline a & 13 & Johanesson (2009) & 0.0258 & 32.96 \\
\hline a & 14 & Klein and Isacks (1998) & 0.0341 & 43.95 \\
\hline a & 15 & Liu et al. (2003) & 0.0287 & 36.71 \\
\hline a & 16 & Macheret and Zhuravlev (1982) & 0.0453 & 57.97 \\
\hline a & 17 & Macheret et al. (1984) & 0.0266 & 33.99 \\
\hline a & 18 & Macheret et al. (1988) & 0.0212 & 27.16 \\
\hline a & 19 & Meier and Bahr (1996) & 0.0143 & 18.31 \\
\hline a & 20 & Radic and Hock (2010) & 0.0267 & 33.29 \\
\hline a & 21 & Van de Wal and Wild (2001) & 0.0152 & 19.43 \\
\hline a & 22 & Yafeng (1981) & 0.0255 & 32.68 \\
\hline a & 23 & Zhuravlev (1985) & 0.0215 & 27.47 \\
\hline a & 24 & Zhuravlev (1988) & 0.0359 & 45.86 \\
\hline$b$ & 25 & Bodin et al. (2010) & 0.0204 & 26.11 \\
\hline$b$ & 26 & Huss and Farinotti (2012) & 0.023 & 30.31 \\
\hline b & 27 & Nicholson et al. (2009) & 0.0264 & 33.74 \\
\hline b & 28 & Ohara et al. (2013) & 0.0177 & 22.69 \\
\hline c & 29 & $\tau 1 \mathrm{a}$ & 0.0222 & 28.47 \\
\hline c & 30 & $\tau 1 \mathrm{~b}$ & 0.0201 & 25.77 \\
\hline c & 31 & $\tau 2 \mathrm{a}$ & 0.0440 & 56.25 \\
\hline c & 32 & $\tau 2 \mathrm{~b}$ & 0.0426 & 54.45 \\
\hline c & 33 & $\tau 3 a$ & 0.0326 & 41.67 \\
\hline c & 34 & $\tau 3 b$ & 0.0314 & 40.11 \\
\hline
\end{tabular}

Probabilistic estimation of glacier volume and glacier bed topography

V. Moya Quiroga et al.

Title Page

\section{Abstract}

Conclusions

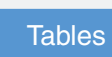

14

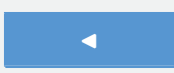

Back
Introduction

References

Figures

$>1$

$\triangleright$

Close

Full Screen / Esc

Printer-friendly Version

Interactive Discussion 
Probabilistic estimation of glacier volume and glacier bed topography

Table 3. Parameters of the different PDFs.

\begin{tabular}{|c|c|}
\hline Distribution & Parameters \\
\hline Beta & $\begin{array}{l}\alpha_{1}=0.93586 ; \alpha_{2}=2.7355 \\
a=0.01428 ; b=0.07984\end{array}$ \\
\hline Exponential & $\lambda=36.227$ \\
\hline Gamma & $\alpha=6.8649 ; \beta=0.00402$ \\
\hline Logistic & $\sigma=0.00581 ; \mu=0.0276$ \\
\hline Lognormal & $\sigma=0.33982 ; \mu=-3.6503$ \\
\hline Normal & $\sigma=0.01054 ; \mu=0.0276$ \\
\hline Weibull & $\alpha=3.6254 ; \beta=0.02933$ \\
\hline
\end{tabular}

V. Moya Quiroga et al.

Title Page

Abstract

Conclusions

Tables

14

Back

Full Screen / Esc

Printer-friendly Version 
Table 4. Evaluation of the PDFs.

\begin{tabular}{lcccccrrr}
\hline Probability distribution & \multicolumn{2}{c}{ Kolmogorov-Smirnov } & & \multicolumn{2}{c}{ Anderson-Darling } & & \multicolumn{2}{c}{ Chi-squared } \\
\cline { 2 - 3 } & Statistic & Rank & & Statistic & Rank & & Statistic & Rank \\
\hline Beta & 0.190 & 6 & & 2.087 & 6 & & 5.648 & 6 \\
Exponential & 0.403 & 7 & & 7.296 & 7 & & 39.194 & 7 \\
Gamma & 0.086 & 2 & & 0.425 & 2 & & 2.655 & 4 \\
Logistic & 0.142 & 5 & & 0.787 & 3 & & 1.119 & 2 \\
Lognormal & 0.071 & 1 & & 0.176 & 1 & & 0.587 & 1 \\
Normal & 0.137 & 4 & & 0.962 & 4 & & 2.786 & 5 \\
Weibull & 0.095 & 3 & & 1.044 & 5 & & 1.831 & 3 \\
\hline
\end{tabular}

Probabilistic estimation of glacier volume and glacier bed topography

V. Moya Quiroga et al.

Title Page

Abstract

Conclusions

Tables

14

4

Back

Full Screen / Esc

Printer-friendly Version

Interactive Discussion 
Table 5. Mean glacier volume and standard deviation according to the different PDFs.

\begin{tabular}{lcccc}
\hline Distribution & $\begin{array}{c}\text { Mean volume } \\
{\left[\mathrm{km}^{3}\right]}\end{array}$ & $\begin{array}{c}\text { Std } \\
{\left[\mathrm{km}^{3}\right]}\end{array}$ & $\begin{array}{c}\text { Variation from } \\
\text { Lognormal mean [\%] }\end{array}$ & $\begin{array}{c}\text { Variation from } \\
\text { Lognormal std [\%] }\end{array}$ \\
\hline Beta & 0.0310 & 0.0132 & 12.60 & 37.28 \\
Exponential & 0.0276 & 0.0276 & 0.25 & 186.60 \\
Gamma & 0.0276 & 0.0105 & 0.25 & 9.45 \\
Logistic & 0.0276 & 0.0105 & 0.25 & 9.45 \\
Lognormal & 0.0275 & 0.0096 & - & - \\
Normal & 0.0276 & 0.0105 & 0.25 & 9.45 \\
Weibull & 0.0264 & 0.0081 & -3.96 & -15.78 \\
\hline
\end{tabular}

Probabilistic estimation of glacier volume and glacier bed topography

V. Moya Quiroga et al.

Title Page

Abstract Introduction

Conclusions References

Tables

Figures

14 I

4

Back Close

Full Screen / Esc

Printer-friendly Version

Interactive Discussion 
Table 6. Confidence values of glacier volume and mean thickness for different degrees of certainty.

\begin{tabular}{lcc}
\hline Conf [\%] & Vol $\left[\mathrm{km}^{3}\right]$ & Thick $[\mathrm{m}]$ \\
\hline 90 & 0.0051 & 4.67 \\
80 & 0.0036 & 3.30 \\
70 & 0.0029 & 2.70 \\
60 & 0.0025 & 2.34 \\
50 & 0.0023 & 2.09 \\
40 & 0.0021 & 1.91 \\
30 & 0.0019 & 1.77 \\
20 & 0.0018 & 1.65 \\
10 & 0.0017 & 1.56 \\
\hline
\end{tabular}

\section{TCD}

$7,3931-3967,2013$

Probabilistic estimation of glacier volume and glacier bed topography

\section{Moya Quiroga et al.}

\section{Title Page}

Abstract

Conclusions

Tables

14

4

Back

Full Screen / Esc

Printer-friendly Version 


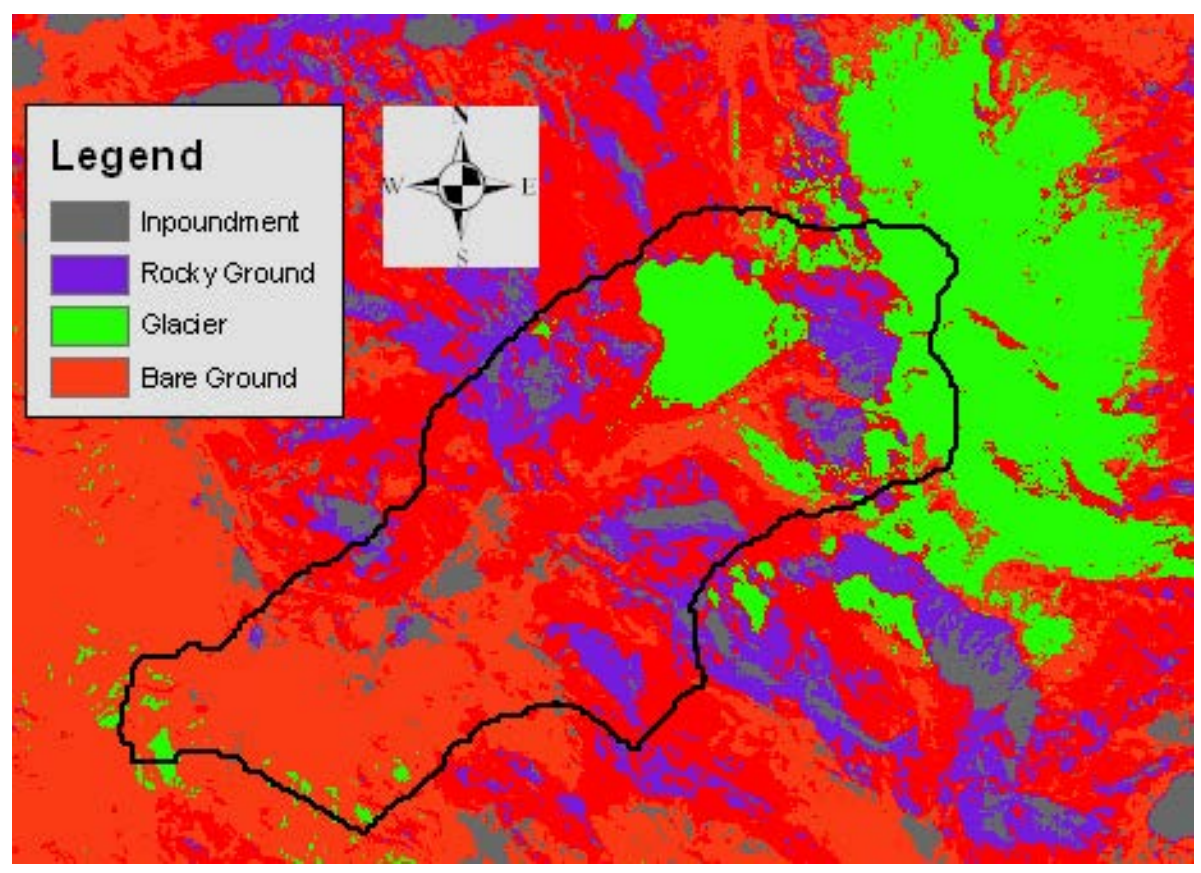

\section{TCD}

\section{7, 3931-3967, 2013}

\section{Probabilistic} estimation of glacier volume and glacier bed topography

\section{Moya Quiroga et al.}

\section{Title Page}

\section{Abstract}

Conclusions

Tables

14

Back

Full Screen / Esc

Printer-friendly Version

Fig. 1. Huayna basin delineation (black line) and different land cover types of the study area. 


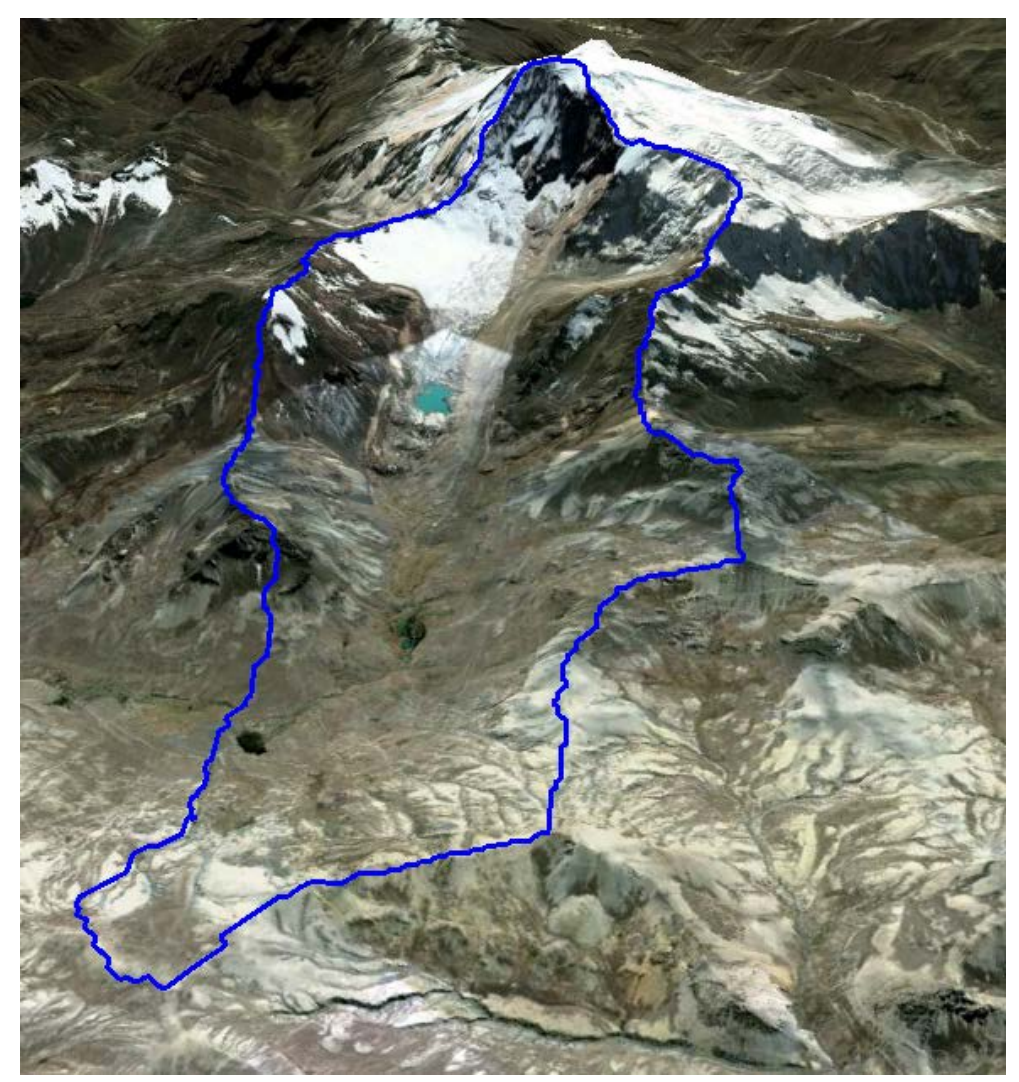

Fig. 2. Study area remote sensing image and basin delineation (blue line). The remote sensing image was obtained from Google Earth.

\section{TCD}

7, 3931-3967, 2013

Probabilistic estimation of glacier volume and glacier bed topography

\section{Moya Quiroga et al.}

\section{Title Page}

Abstract

Conclusions

\section{Tables}

14

$\triangleleft$

\section{Back}

\section{Full Screen / Esc}

Printer-friendly Version 


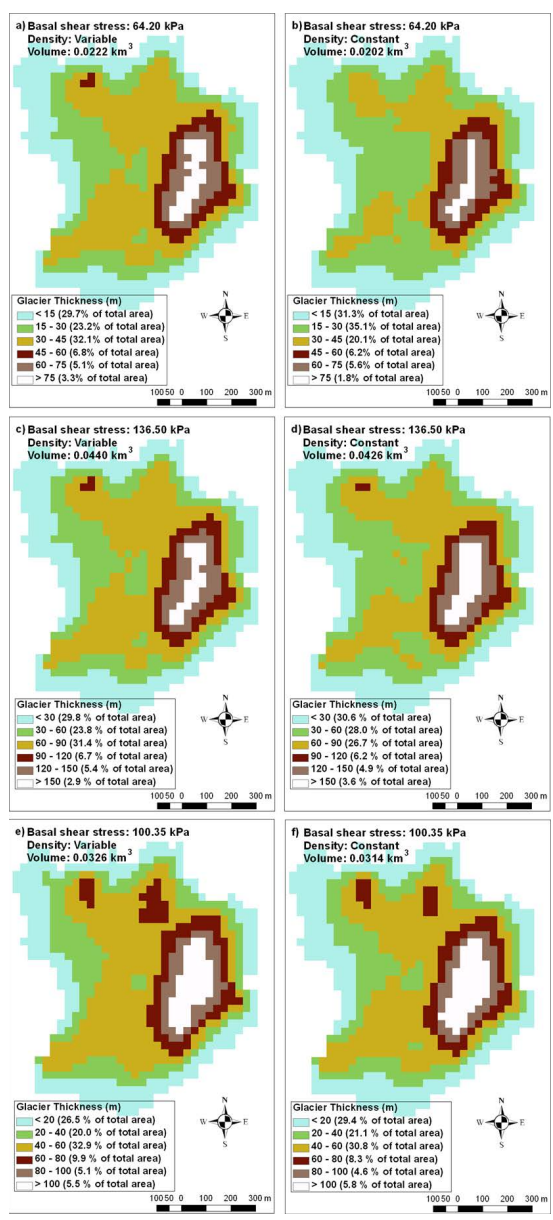

Fig. 3. Huayna West glacier thickness considering different values of basal shear stress, constant glacier density and variable glacier density.
TCD

$7,3931-3967,2013$

Probabilistic estimation of glacier volume and glacier bed topography

V. Moya Quiroga et al.

\section{Title Page}

Abstract

Conclusions

Tables

14

Back

Full Screen / Esc

Printer-friendly Version

Interactive Discussion
References

Figures

- I

Close 


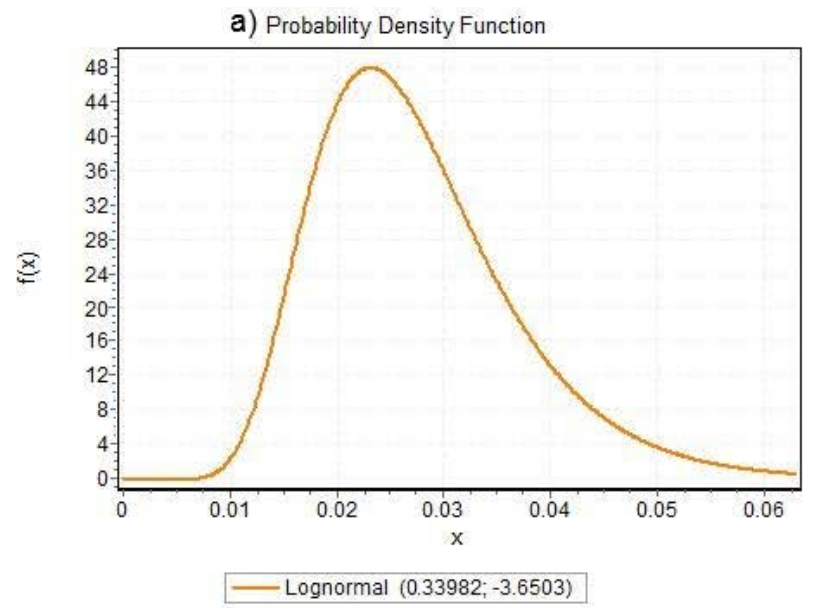

\section{TCD}

\section{7, 3931-3967, 2013}

Probabilistic estimation of glacier volume and glacier bed topography

\section{Moya Quiroga et al.}

b) Cumulative Distribution Function

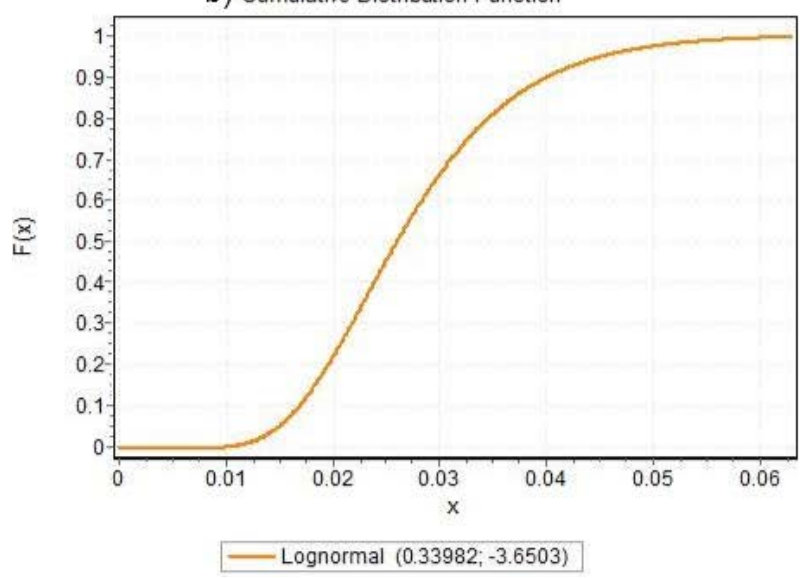

Title Page

Abstract

Conclusions

Tables

14

4

Back

\section{Full Screen / Esc}

Printer-friendly Version

Interactive Discussion Fig. 4. Probability distribution function of the
tion function of the Huayna West volume (b). 


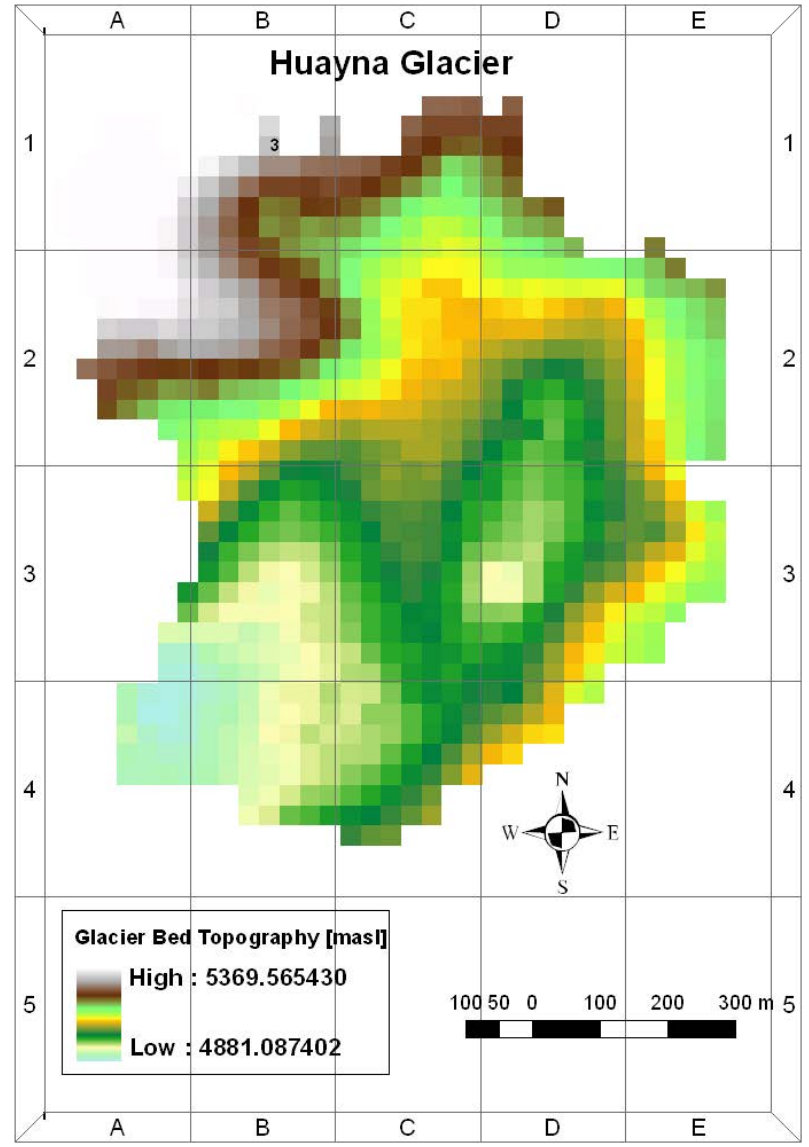

TCD

7, 3931-3967, 2013

Probabilistic estimation of glacier volume and glacier bed topography

V. Moya Quiroga et al.

\section{Title Page}

\section{Abstract}

Conclusions

Tables

14

Back

\section{Full Screen / Esc}

Printer-friendly Version

Interactive Discussion 